\title{
The Study on Factors Influencing Incomes of Laborers in Viet Nam: The Case at Industrial Parks, Economic Zones in Travinh Province
}

\author{
Ha Hong Nguyen ${ }^{1} \&$ Tuyen Thanh Nguyen ${ }^{2}$ \\ 1 Department of Banking and Finance, Tra Vinh University, Viet Nam \\ ${ }^{2}$ Viet Nam Journal of Development and Integration, Viet Nam \\ Correspondence: Ha Hong Nguyen, Associate Professor, Ph.D; Head of Department of Banking and Finance, Tra \\ Vinh University, Viet Nam. E-mail: hongha@tvu.edu.vn, honghaicbtv@yahoo.com.vn
}

Received: February 21, 2020

Accepted: June 22, 2020

Online Published: September 5, 2020

doi:10.5430/rwe.v11n5p321

URL: https://doi.org/10.5430/rwe.v11n5p321

\begin{abstract}
This study aims to solve the problem of raising incomes, improving the quality of life of Vietnamese workers in industrial parks and economic zones today, specifically in Tra Vinh province, Viet Nam. By the method of primary data collection of 300 employees working in enterprises in Long Duc Industrial Park located in Tra Vinh City; Co Chien Industrial Park located in Cang Long district and Dinh An economic zones located in Tra Cu district; using multivariate regression model; The study showed that there are 6 factors affecting the income of workers: the occupation of workers, working experience, the qualifications of workers, ethnicity, Religion and working environment. In particular, working experience, the qualifications of workers greatly affect the income of employees. From the research results, the author have proposed solutions to improve the income of workers, ensure social security and stabilize the lives of workers in the future.
\end{abstract}

Keywords: workers, enterprises, multivariate regression, salaries, industrial parks, economic zones

JEL Classification Code: E24, H55, J31, J62, M54

\section{Introduction}

The goal of every country in the world is to create sustainable jobs for all people (Sandra Polaski, 2014), who are capable of working and wanting to work for the best way out of poverty, and the main factor to attract workers are wages, salaries and income. According to the Central Institute for Economic Management (2015), "wages is a part of national income distributed to the workers, and it is influenced by a number of factors such as the level of production development, the relationship between accumulation and consumption in each period, and the policies of the state to perform political economic tasks in that period. Thus, the wages of workers depend on the socio-economic situation of the country. If the economic conditions develop together with the advanced technology, the labor productivity increases. Also, the wages and incomes of laborers increase. Salary policies are significant for socio-economic situations and increasing salary reasonably can be considered a healthy stimulus measure (Central Institute for Economic Management, 2015). According to Nguyen Huu Dung, wage policy is one of the most important aspects of the market economy, and wage policy is an integrated problem that has strong political, social and economic relations (Nguyen, 2010).

In recent years, Tra Vinh province has implemented many policies to attract investment, create jobs for workers; in 2018, creating jobs for 61,170 laborers (Source: Report on implementation of socio-economic development tasks in Tra Vinh province in 2018); Compared to the provincial average income per capita, the average income of employees increases 17.47 million VND / person / year due to the adjustment of regional minimum wage, due to the economic growth rate (GRDP) of 11, 05\%, ranked the second in terms of economic growth in the Mekong Delta region, but the income of workers is not really guaranteed for family spending as well as a need for accumulation, from which leading to a low life for workers.

These are related to ownership, resource allocation, accumulation and consumption, human resources development, and social security. TraVinh currently has about 1,819 non-state opened enterprises. Of which, there are 1,794 private enterprises and 25 foreign-invested enterprises (TraVinh Statistical Office, 2019). The number of employees in 
Industrial parks is 17,172 , an increase of $16 \%$ compared to $2016 \ldots$ Of which, the average salary in this area is 5,590,000 VND / person / month (TraVinh Statistical Office, 2018).

\section{Literature Review}

One's salary depends on his or her age (Bojas, 2005). Wage is relatively low for young workers, and it rises as they are mature and accumulate human capital, and can be mitigated for older workers. This can be presented through the relationship and the number of years of schooling by a "school-based salary curve" showing the wages of the firms willing to pay correspondingly for each educational level, and the relationship between wages and years of schooling (Mincer, 1974; Borjas, 2005). Normally, agricultural workers are paid less than those who work in industry and services, and in the same occupation, the income of workers depends on the profession (type of work) and work experience of employees due to complex jobs paid higher than simple jobs and those with longer working hours are likely to be quick to complete and better than the less experienced, so they are paid higher. (Mincer, 1974; Bojas, 2005). According to Pham Thi Phong Lan and Truong Hoang Minh (The current technical and financial status of the crab fishing industry in the PhuQuoc island, Kien Giang province, 2014), the experience is the biggest factor influencing the income, especially in the traditional fishing trade. The author used the direct interview method and then encoded the data to calculate the mean, standard deviation, maximum, minimum and percent value. The differences will be compared through ANOVA and T-test with a significance level of 5\%. Also, the author used a multivariable regression of independent variables that affect yield and profit.

Pham Le Thong (2012) re-evaluates the profitability of learning and provides further evidence of the benefits of education for learners in a market economy. The author selected the study subjects as wage earners in the Mekong delta. The results of the estimation of the personal income function show that education is the most important factor determining personal income. The author also used the descriptive statistics tool of the variables in the model. Nguyen Quoc Nghi and Bui Van Trinh (2010) used a stratified data collection method in combination with a random sampling method and then used a linear regression model to determine the factors affecting the per capita income of the ethnic minority household. Through the research results, a number of solutions will be recommended to improve theincome stability for the Cham and the Khmer ethnic people. The results of the study are the scientific basis for relevant agencies in the formulation of policies related to social security for ethnic minorities in the Mekong Delta in particular and the whole country in general.

Pham Viet Hung, Tran Hoang Nam, Nguyen Thi Ai Lac and Su Thi Hang Hang (2010), used the descriptive statistics method, eliminated the wrong variable markers, tested the model's fit, tested the multi-collinear phenomenon, tested the variance of the variance by comparison method to squared value. Then the authors analyzed the variables and gave several policy suggestions. According to Dinh Phi Ho (2015), official credit impacts on household income in Vietnam, the author used a linear regression model with cross-sectional data that provides an analytical framework with 10 factors affecting household income in rural areas. To ensure the reliability of the regression model, the author used the following tests, including partial correlation test of regression coefficient, model fit test, multi-collinearity test, self-correlation and covariance of residuals varied with comparison with squared values. Then the author used the normalized coefficients of conversions to form the percentages to determine the order of influence of the factors.

In general, the above studies focus on addressing the income issues of workers in a region, a determined locality. researches has not been conducted in a province as Tra Vinh, Viet Nam regarding the assessment of factors affecting the income of employees in the Industrial Park, Economic Zone of Tra Vinh Province, Vietnam, one of the countries has a strong development in industrial parks and economic zones in Asia. Studies have considered that social welfare and work environment are important conditions to improve income in the current situation and the studies have not solved specific issues for workers in Economic Zones and Industrial Parks. Since then, this study has uniquely found the improvement of income and living conditions of workers in Economic and Industrial Zones in Vietnam.

\section{Materials and Methods}

Research models: Based on relevant domestic and foreign studies. The author proposes a model to study the factors influencing the income of workers in Industrial Parks and Economic Zones, Tra Vinh province, Viet Nam:

$$
\mathrm{Y}_{\mathrm{i}}=\mathrm{b}_{0}+\mathrm{b}_{1} \mathrm{X}_{1}+\mathrm{b}_{2} \mathrm{X}_{2}+\mathrm{b}_{3} \mathrm{X}_{3}+\ldots+\mathrm{b}_{6} \mathrm{X}_{6}+\mathrm{u}
$$

Inside:

\footnotetext{
- Dependent variable is Salary, symbol Y: (unit: 1000 VND /person/month)

- Independent variables Xi ( $\mathrm{i}=1$ - 6) include: job, experience, qualification, ethnicity, religion, working environment.
} 


\section{Data and Implementation Methods}

The study was conducted by interviewing directly 300 workers (according to the sample size of Hoang Trong and Chu Nguyen Mong Ngoc, 2008), currently working in 10 enterprises at Industrial Parks and Economic Zones in Tra Vinh Province, Viet Nam by the method of multivariate regression analysis with table 1.

Table 1. Factors influencing wages of labourers

\begin{tabular}{|c|c|c|c|}
\hline Variable name & $\begin{array}{l}\text { Symbol } \\
\text { Variable }\end{array}$ & Basic selection of variables & $\begin{array}{l}\text { Expect } \\
\text { mark }\end{array}$ \\
\hline Incomes & $\mathrm{Y}$ & Mincer (1974); Dinh Phi Ho (2012) & \\
\hline Job & $\mathrm{X}_{1}$ & $\begin{array}{l}\text { Pham Viet Hung et al., (2017); Pham Thi Phong Lan and } \\
\text { Truong Hoang Minh (2014) }\end{array}$ & + \\
\hline Experience & $\mathrm{X}_{2}$ & Mincer (1974); Dinh Phi Ho (2012); Bojas (2005) & + \\
\hline Qualification & $\mathrm{X}_{3}$ & Mincer (1974); Dinh Phi Ho (2012); Pham Le Thong (2008) & + \\
\hline Ethnicity & $\mathrm{X}_{4}$ & Nguyen Quoc Nghi \& Bui Van Trinh (2011) & $+/-$ \\
\hline Religion & $\mathrm{X}_{5}$ & Consulting experts' ideas & + \\
\hline Work environment & $\mathrm{X}_{6}$ & $\begin{array}{l}\text { Le Nguyen Doan Khoi \& Bui Thi Thu Minh (2014); Chu Thi } \\
\text { Lan \& Quyen Ha (2014) }\end{array}$ & + \\
\hline
\end{tabular}

Source: aggregate from studies

Table 2. Regression results of the model multi-collinear

\begin{tabular}{llllll}
\hline Variables & Coefficient & Standard error & $\mathbf{t}$ & Sig & VIF \\
\hline Job $\left(\mathbf{X}_{\mathbf{1}}\right)$ & $2783.982^{* * *}$ & 215.91 & 12.8 & 0.000 & 1.615 \\
Experience $\left(\mathbf{X}_{\mathbf{2}}\right)$ & $83529^{* * *}$ & 15.03 & 5.55 & 0.000 & 1.345 \\
Qualification $\left(\mathbf{X}_{\mathbf{3}}\right)$ & $82027.46^{* *}$ & 29265.15 & -2.24 & 0.026 & 1.634 \\
Ethnicity $\left(\mathbf{X}_{4}\right)$ & $-367138.6^{* * *}$ & 80251.67 & -4.57 & 0.000 & 1.144 \\
Religion $(\mathbf{X 5})$ & $80959.21^{* *}$ & 36873.73 & 2.20 & 0.030 & 2.152 \\
Work environment $(\mathbf{X 6 )})$ & $-311.47^{* *}$ & 110.35 & -2.82 & 0.005 & 1.077 \\
Constant & 1483428 & 252421.90 & 5.88 & 0.000 & 1.615 \\
\hline
\end{tabular}

R2 adjustment: 0,7182; Statistical value F: 31,25; Prob value> F: 0.000.

Note: *** Significance level 1\%, ** Significance level 5\%,

a. Dependent Variable: Incomes

\section{Results and Disscussion}

To determine the factors affecting the income of laborers in non-state enterprises in TraVinh province, multivariate regression analysis andaverage accreditation were used. In order to test the multi-collinearity in the model, testing through the multipliers of the variance (VIF) of the variables was not found to be multi-collinear. According to Table 2, the regression results show that: the labor force, experience has a significance level of $1 \%$; working environment has a meaningful 5\%; education, skills, ethnicity, religion have meaning 10\%, affecting the salary of workers in non-state enterprises in TraVinh province. (Truong Vinh Phuoc, 2017).

\section{Policy Implications}

The government of Tra Vinh Province should develop welfare policies for workers: The State needs to provide policy support and legal assistance in the settlement of employee remuneration and labor disputes for laborers and employers. Businesses need to support additional costs to ensure the minimum living standard of workers. This will help them reduce the cost of part of the employee's total income

Flexible salary mechanism should be put into operation: Proposing the minimum wage should provide a method of calculation that is appropriate to the changes in the financial market, and should be fully accounted for, including housing, consumption, electricity and water costs. Stabilizing macroeconomics, consumer goods prices, and essential 
goods and especially stabilizing financial markets and monetary units would be important. Also, it should be necessary to increase the cumulative capacity of workers, by improving the efficiency of labor market management by the law of minimum wage and personal income tax, corporate income tax. Improving employee incomes to increase long-term accumulation should be noted.

Employers of Enterprises must have financial policies to support employees working in Industrial parks: Trade unions and socio-political organizations should be encouraged to set up a savings fund to support workers. Also, investors should be encouraged to create more demand in the labor market to create jobs and push up labor prices, leading to higher wages and incomes for workers, thus boosting the people's living standards. The increase in domestic consumption demand creates a momentum for sustainable economic growth and the market for other products consumption to support the domestic market. To do so, the first thing to do is to create a favorable business environment to attract investors by perfecting legal institutions and regulations in the legal system. This would motivate investors with advanced management skills, advanced science technology and technology transfer to train highly skilled laborers to meet their work demands.

It is better to develop an effective working environment: Enterprises should also create a favorable and safe working environment for workers. The state sector plays animportant role in providing regulations, policies, welfare and public services such as health, high quality education for workers, stabilizing and regulating labor market balance, and synchronizing solutions to support the demand to encourage investors to participate in the labor market segment. Moreover, supply-side measures should be adopted to increase access to employment and the conditions for workers to improve their skills.

Improving the effectiveness of the vocational training should be taken into account: The state should support enterprises or vocational training centers for workers in the informal market to improve their qualifications and ability to seek their own income. At the same time, tax cuts for businesses create more jobs for the informal sector. On the other hand, it is better to examine the benefits of corporate welfare policies for workers working for them in the informal and official markets.

\section{Acknowledgements}

The author sincerely thank the support and assistance of the survey team of Faculty of Economics, Tra Vinh University; Social Insurance of Tra Vinh Province, Viet Nam, and 300 employees working 10 Enterprises at Long Duc Industrial Park located in Tra Vinh City; Co Chien Industrial Park located in Cang Long district and Dinh An economic zones in Tra Vinh Province. The authors sincerely thank the enthusiastic support of these research groups.

\section{References}

Borjas. (2013). Labor Economics (4th ed.). McGraw-Hill/Irwin Hardcover, pp. 24-29.

Bui, T. M. T., \& L. N. D. K. (2014). The study on the factors influencing the motivation of direct production staff in Vietnam Machinery Installation Corporation (LILAMA). The Scientific Journal of Can Tho University, (35), 66-78.

Central Institute for Economic Management. (2015). The Role of Salary and Income as a motive of Subtainable Economic Growth, (8), 13-15.

Chu, T. L., \& Q. H. (2014). Factors affecting the quality of employment of employees in informal production establishments in Hanoi. Journal of Science and Development, 12(6), 955-963.

Dinh, P. H. (2015). Official Credit Impacts on Household Income in Vietnam. Journal of Economic Development, (2), 65-82

Hoang, T., \& Chu, N. M. N. (2008). Data Analysis with SPSS. Hong Duc Publishing House, pp. 23-28.

Hua, T. P. C., \& Nguyen, M. D. (2016). Factors Affecting Household Income Diversification in the Mekong Delta. Journal of Science, Van Hien University, 4(3), 46-55.

Mincer, J. (1974). Schooling, Experience and Earnings. New York: Columbia University Press.

Nguyen, H. D. (2010). Social Security Policy System in Vietnam: Situation and Development Orientation. VNU Journal of Science, Economics and Business, 26(2010), 118-128.

Nguyen, Q. N., \& Bui, V. T. (2010). Factors Affecting Income of Ethnic Minorities in the Mekong Delta. Journal of Science, Cantho University, (18a), 240-250. 
Pham, L. T. (2008). The Impact of Education on Income of Laborers in the Mekong Delta. Economic Research No. 412 - September 2012, pp. 63-69.

Pham, T. P. L., \& Truong, H. M. (2014). The current technical and financial status of the crab fishing industry in the coastal area of PhuQuoc Island, KienGiang Province. Scientific Journal of Can Tho University, (33), 138.

Pham, V. H. et al.. (2017). Factors affecting income of laborers in Ho Chi Minh City. Hue University Journal of Science: Economics and Development, 126(5D). https://doi.org/10.26459/hueuni-jed.v126i5D

Sandra, P. (2014). Global Wage Policy: Regional and Country - Trends and Challenges. Vietnam National Wages Seminar, Hanoi, 11th, 2014.

Tra Vinh Stastitical Office. (2019). The Report on the number of employees and enterprise, pp. 32-38.

Truong, V. P. (2017). Factors affecting income of laborers in non-state enterprises in TraVinh city (Masters thesis). TraVinh University, pp. 23-34.

\section{Copyrights}

Copyright for this article is retained by the author(s), with first publication rights granted to the journal.

This is an open-access article distributed under the terms and conditions of the Creative Commons Attribution license (http://creativecommons.org/licenses/by/4.0/). 